\title{
APLIKASI IMPORTANCE PERFORMANCE ANALYSIS UNTUK PERBAIKAN KINERJA PENGELOLAAN PENYEDIAAN AIR MINUM BERKUALITAS (Studi Kasus PDAM Tirta Dharma)
}

\author{
Irma Susanti ${ }^{1)}$, Agus Martono Hadi Putranto ${ }^{2)}$, Teguh Adiprasetyo ${ }^{3)}$ \\ 1) UPTD Laboratorium Dinas Kesehatan Kota Bengkulu \\ ${ }^{2)}$ Dosen Jurusan Kimia Fakultas MIPA UNIB \\ ${ }^{3)}$ Dosen Jurusan Agroteknologi Fakultas Pertanian UNIB
}

\begin{abstract}
ABSTRAK
Telah dilakukan analisis persepsi konsumen dan manajemen PDAM Tirta Dharma terhadap kualitas air bersih PDAM dan air Sungai Bengkulu. Penelitian ini bertujuan untuk mengetahui persepsi konsumen dan manajemen PDAM terhadap kualitas air PDAM yang air bakunya berasal dari air Sungai Bengkulu dan untuk mengetahui kualitas air PDAM dan air Sungai Bengkulu berdasarkan pemeriksaan laboratorium secara fisika, kimia dan bakteriologi sesuai dengan Permenkes RI No. 416/Menkes/Per/IX/1990 tentang Syarat-Syarat dan Pengawasan Kualitas Air dan Peraturan Daerah Propinsi Bengkulu No. 6 Tahun 2005 tentang Penetapan Baku Mutu Air dan Kelas Air Sungai Lintas Kabupaten/Kota dalam Propinsi Bengkulu. Metode pengumpulan data dengan cara menyebarkan kuisioner kepada konsumen dan manajemen PDAM yang diukur dengan skala likert dan dianalisis dengan metode IPA (Importance Performance Analisis), pengujian sampel air Sungai Bengkulu dan air PDAM. Persepsi konsumen menyatakan bahwa kualitas air PDAM belum baik dengan rata-rata skor 2,28 sedangkan menurut persepsi manajemen PDAM kualitas air PDAM sudah cukup baik dengan nilai rata-rata skor 3,24. Dari hasil analisis IPA, ada 3 faktor yang harus menjadi prioritas utama pihak manajemen yaitu: Air PDAM memiliki air yang jernih, Air PDAM tidak mengandung zat kimia beracun dan setiap keluhan terhadap air PDAM ditanggapi dengan cepat oleh petugas. Berdasarkan pemeriksaan laboratorium secara fisika, kimia dan bakteriologi pada air Sungai Bengkulu ditemukan bahwa jumlah residu terlarut sebesar $1795 \mathrm{mg} / \mathrm{l}$, kadar cadmium $(\mathrm{Cd})$ 0,201 $\mathrm{mg} / \mathrm{l}$ dan kadar timbal $(\mathrm{Pb})$ sebesar $0,33 \mathrm{mg} / \mathrm{l}$, sedangkan pada sampel air PDAM tidak di temukan timbal. Hasil uji bakteriologi coliform pada air sungai Bengkulu lebih dari 1898.
\end{abstract}

Kata kunci: kualitas air, Importance Performance Analysis, air baku, air minum

\section{PENDAHULUAN}

Air merupakan sumber daya alam yang diperlukan untuk hajat hidup orang banyak, bahkan oleh semua makhluk hidup. Kualitas air sangat menentukan kesehatan manusia, menurut laporan United National Environtmental Program (UNEP) setiap tahun jumlah balita yang meninggal karena penyakit yang berkaitan dengan buruknya kualitas air mencapai 1,8 juta jiwa (The Jakarta Post, 24 Maret 2010 dalam Wiryono 2012). Di negara-negara maju pemerintah menerapkan baku mutu yang tinggi untuk air minum sehingga airnya aman di konsumsi langsung dari keran, sebaliknya di negara-negara berkembang meskipun ada baku mutu untuk air minum, tetapi pemerintah tidak mampu menerapkannya sehingga kualitas air minumnya buruk (Wiryono, 2012). Perhatian pemerintah pada pembangunan ekonomi sering mengorbankan kualitas air, berdasarkan amanat Undang-Undang No. 7 Tahun 2004 tentang Sumber Daya Air (SDA); dalam menghadapi ketidakseimbangan antara ketersediaan air yang cenderung menurun dan kebutuhan air yang semakin meningkat, SDA wajib dikelola dengan memperhatikan fungsi sosial, lingkungan hidup dan ekonomi secara selaras.

Air Sungai Bengkulu merupakan salah satu sumber air yang melintasi Kota Bengkulu dan Kabupaten Bengkulu Tengah yang digunakan untuk berbagai kegiatan seperti kebutuhan domestik (air minum, mandi cuci), sumber air irigasi, sumber air PDAM dan sumber penghidupan (ikan, udang, pasir, batu kali) 
(BLH Propinsi Bengkulu, 2012). Air Sungai Bengkulu dimanfaatkan sebagai sumber air baku untuk PDAM Kota Bengkulu selain air baku dari Sungai Nelas. Berdasarkan data kependudukan Tahun 2012 jumlah penduduk Kota Bengkulu 329.473 jiwa dengan cakupan pelayanan PDAM 142.330 jiwa $(43,20$ $\%)$. Air Sungai Bengkulu melalui Instalasi Pengelolaan Air (IPA) Surabaya melayani 3 kecamatan yaitu Teluk Segara, Sungai Serut dan Muara Bangkahulu. Berdasarkan data PDAM, jumlah penduduk yang terdapat di wilayah IPA Surabaya sebanyak 75.977 jiwa dengan jumlah penduduk terlayani sebanyak 8.077 jiwa atau sebesar 10,63\%.(Buletin PDAM Tirta Dharma Bengkulu, 2013).

Berdasarkan laporan hasil pemantauan kualitas Air Sungai Bengkulu oleh Tim Terpadu (SPT Gubernur Bengkulu No. 80/3340/KBPIM Tanggal 24 Mei 2011) yang melakukan peninjauan, pendataan, serta penelitian terhadap pencemaran dan ekosistim DAS Air Bengkulu disimpulkan bahwa telah terjadi penurunan kualitas air dari Kelas I untuk Air Baku Air Minum menjadi Kelas III untuk Perikanan, Pertanian dan Peternakan (BLH Propinsi Bengkulu, 2012). Kebijakan Pemerintah Daerah Kota Bengkulu belum mampu melindungi perairan Sungai Bengkulu, adanya sejumlah aktifitas di hulu sungai seperti pertambangan, pabrik pengelolaan karet dan pertanian serta perkebunan mempengaruhi kualitas air Sungai Bengkulu. Kondisi ini tentu akan mempengaruhi kinerja pengelolaan PDAM, khususnya kinerja pelayanan penyediaan air minum yang berkualitas kepada konsumen. Untuk itu perlu di lakukan analisis kinerja manajemen PDAM dan analisis kualitas air secara fisika, kimia dan bakteriologi terhadap sumber air baku PDAM yang berasal dari air Sungai Bengkulu agar dapat diidentifikasi peluang-peluang untuk perbaikan kinerja.

\section{METODE}

Penelitian dilakukan pada Januari Februari 2014 dengan kerangka pemikiran ditunjukkan pada Gambar 1. Sumber data dalam penelitian ini adalah data primer yaitu data yang diperoleh langsung dari sumber objek penelitian. Teknik pengumpulan data yang digunakan dalam penelitian adalah dengan pengujian sampling air Sungai Kota Bengkulu dan air PDAM yang diambil pada 4 titik, dan penggunaan kuesioner, responden dipilih dengan teknik purposive sampling (sample bertujuan) yang terdiri kepada 15 orang konsumen, dan 15 orang manajemen PDAM yang mengetahui objek (Sungai Bengkulu) serta konsumen PDAM untuk mengetahui persepsinya terhadap kualitas air PDAM Tirta Dharma Kota Bengkulu.

Lokasi pengambilan sampel :

1. Air sungai (baku) diambil sebelum intake PDAM Surabaya

2. Air PDAM di reservoir PDAM Instalasi Pengolahan Air Surabaya.

3. 3 sampel dari air PDAM di rumah masyarakat mewakili range dekat, sedang dan jauh yang terdapat di 3 Kecamatan.

a. Range dekat : Kelurahan Surabaya, Kecamatan Sungai Serut

b. Range Sedang : Kelurahan Kandang Limun, Kecamatan Muara Bangkahulu

c. Range Jauh : Kelurahan Malabero, Kecamatan Teluk Segara

Pemeriksaan laboratorium mencakup fisika, kimia dan bakteriologi, analisis kimia dilakukan untuk $\mathrm{pH}$, logam berat Timbal $(\mathrm{Pb})$ dan Cadmium $(\mathrm{Cd})$. Pemilihan kedua logam berat ini karena berdasarkan penelitian di amerika Serikat diperkirakan terdapat lebih dari seratus ribu anak yang IQ-nya turun sampai lima poin karena air minum mereka mengandung Timbal (Chiras and Reganold, 2005 dalam Wiryono 2012) dan kasus keracunan pada masyarakat di Jepang yang dikenal dengan penyakit "itaiitai" yang merusak sistem fisiologi tubuh 
akibat air minum mereka mengandung Cadmium (Herman, 2006). Pemeriksaan Cadmium di lakukan di Laboratorium Dinas Kesehatan Kota Bengkulu dengan alat Spektrofotometer dan Timbal di Balai POM Bengkulu dengan alat Spektrophotometer Serapan Atom (SSA).

Dalam penelitian ini, analisis kuantitatif yang digunakan adalah analisis kuantitatif sederhana yakni analisis frekuensi, rata-rata dan persentase. Tujuannya mengetahui persepsi rata-rata jawaban responden terhadap variabel penelitian. Gay dan Diehl mengungkapkan bahwa dalam suatu penelitian, menggunakan sampel minimal sebanyak 30 orang responden, dan Sekaran (2006) memberikan pedoman penentuan jumlah sampel, sebaiknya ukuran sampel minimum harus 30 orang responden. Oleh karena itu untuk melihat persepsi masyarakat juga diberikan kuesioner kepada konsumen dan manajemen PDAM dengan jumlah responden sebanyak 30 orang. Persepsi responden diukur dengan skala likert mulai dari "sangat tidak setuju" dengan skor 1 sampai dengan "sangat setuju" dengan skor 5. Selanjutnya, untuk melihat skor rata-rata jawaban responden, dihitung rumus rata-rata jawaban dengan rumus :

Dimana :

$$
X=\sum \frac{f \cdot s}{N}
$$

$\mathrm{X}=$ nilai rata-rata

$\mathrm{F}=$ frekuensi jawaban responden

$\mathrm{S}=$ Skor jawaban responden

$\mathrm{N}=$ Jumlah responden adalah :

Alat ukur dalam penelitian ini

Tingkat Persepsi
5
4
3
2
1

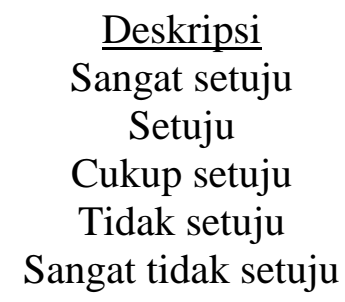

Selanjutnya untuk mengukur jarak interval rata-rata dipergunakan hasil dari perhitungan pengukuran sebagai berikut :

- Nilai terendah dari kelas adalah $1 \times 1=1$

- Nilai tertinggi dari kelas adalah $1 \times 5=5$

- Interval kelas adalah (5-1):5 =0,8

Dari hasil perhitungan di atas diperoleh angka hitung jarak interval sebesar 0,8. Dengan demikian maka jarak interval yang dipergunakan untuk mengukur persepsi responden terhadap variabel penelitian adalah sebagai berikut :

$\frac{\text { Interval }}{1-1,8}$
$1,81-2,6$
$2,61-3,4$
$3,41-4,2$
$4,21-5$

\author{
$\underline{\text { Deskripsi }}$ \\ Sangat tidak baik \\ Tidak baik \\ Cukup baik \\ Baik \\ Sangat baik
}

Analisis deskriptif dilakukan
dengan cara menghitung distribus frekuensi, rata-rata dan persentase terhadap pilihan jawaban yang diberikan oleh responden terhadap variabel-variabel yang digunakan dalam penelitian ini. Untuk pengumpulan data sebagai pendukung analisis dari responden digunakan teknik wawancara terstruktur dimana responden akan diberikan pertanyaan yang sudah dipersiapkan dan akan diberikan pertanyaan yang sama kepada setiap responden untuk memperoleh informasi secara langsung dan mendalam dari responden sehingga dapat diambil kesimpulan pendapat dari responden sebagai bahan analisis hasil penelitian (Sekaran, 2006).

Setelah dilakukan uji validitas dan reliabilitas dan didapatkan bahwa 13 variabel telah valid dan kuesioner telah dinyatakan reliabel maka analisis dapat dilanjutkan dengan menggunakan metode Importance Performance Analysis (IPA). Teknik analisis IPA telah banyak digunakan untuk menilai kinerja manajemen beberapa sektor (Miranda, et al., 2010; Wade and Eagles, 2003; Wong et al., 2010), namun IPA belum pernah digunakan untuk penilaian kinerja PDAM. 
IPA bertujuan untuk menampilkan informasi berkaitan dengan faktor-faktor pelayanan yang menurut pelanggan sangat memengaruhi loyalitas dan kepuasan mereka, dan faktor-faktor pelayanan yang menurut pelanggan perlu ditingkatkan karena kondisi saat ini belum memuaskan pelanggan. IPA menyatukan pengukuran faktor tingkat kinerja (performance) dan tingkat kepentingan (importance) yang kemudian digambarkan dalam diagram dua dimensi yaitu diagram importanceperformance untuk mendapatkan usulan praktis dan memudahkan penjelasan data. Pada tingkat kinerja, pengukuran dilakukan dengan mengukur tingkat kepuasan pelanggan terhadap pelayanan yang telah dirasakan. Grafik IPA dibagi menjadi empat buah kuadran berdasarkan hasil pengukuran importance-performance, yaitu:

1. Kuadran satu, "Concentrate Here" (high importance \& low satisfaction) Faktor-faktor yang terletak dikuadran ini dianggap sebagai faktor yang sangat penting oleh konsumen namun kondisi pada saat ini belum memuaskan sehingga pihak manajemen berkewajiban pengalokasikan sumber daya yang memadai untuk meningkatkan kinerja berbagai faktor tersebut. Faktor-faktor yang terletak pada kuadran ini merupakan prioritas untuk ditingkatkan.
2. Kuadran dua, "Keep up The Good Work" (high importance \& high satisfaction). Faktor-faktor yang terletak dikuadran ini dianggap sebagai faktor penunjang bagi kepuasan konsumen sehingga pihak manajemen berkewajiban memastikan bahwa kinerja institusi yang dikelolanya dapat terus mempertahankan prestasi yang telah dicapai.

3. Kuadran tiga, "Low Priority" (low importance \& low satisfaction) Faktor-faktor yang terletak dikuadran ini mempunyai tingkat kepuasan yang rendah dan sekaligus dianggap tidak terlalu penting bagi konsumen, sehingga pihak manajemen tidak perlu memprioritaskan atau terlalu memberikan perhatian pada faktor faktor tersebut.

4. Kuadran empat, "Possible Overkill" (low importance \& high satisfaction) Faktor-faktor yang terletak dikuadran ini dianggap tidak terlalu penting sehingga pihak manajemen perlu mengalokasikan sumber daya yang terkait dengan faktor-faktor tersebut kepada faktor-faktor lain yang mempunyai prioritas penanganan lebih tinggi yang masih membutuhkan peningkatan. 


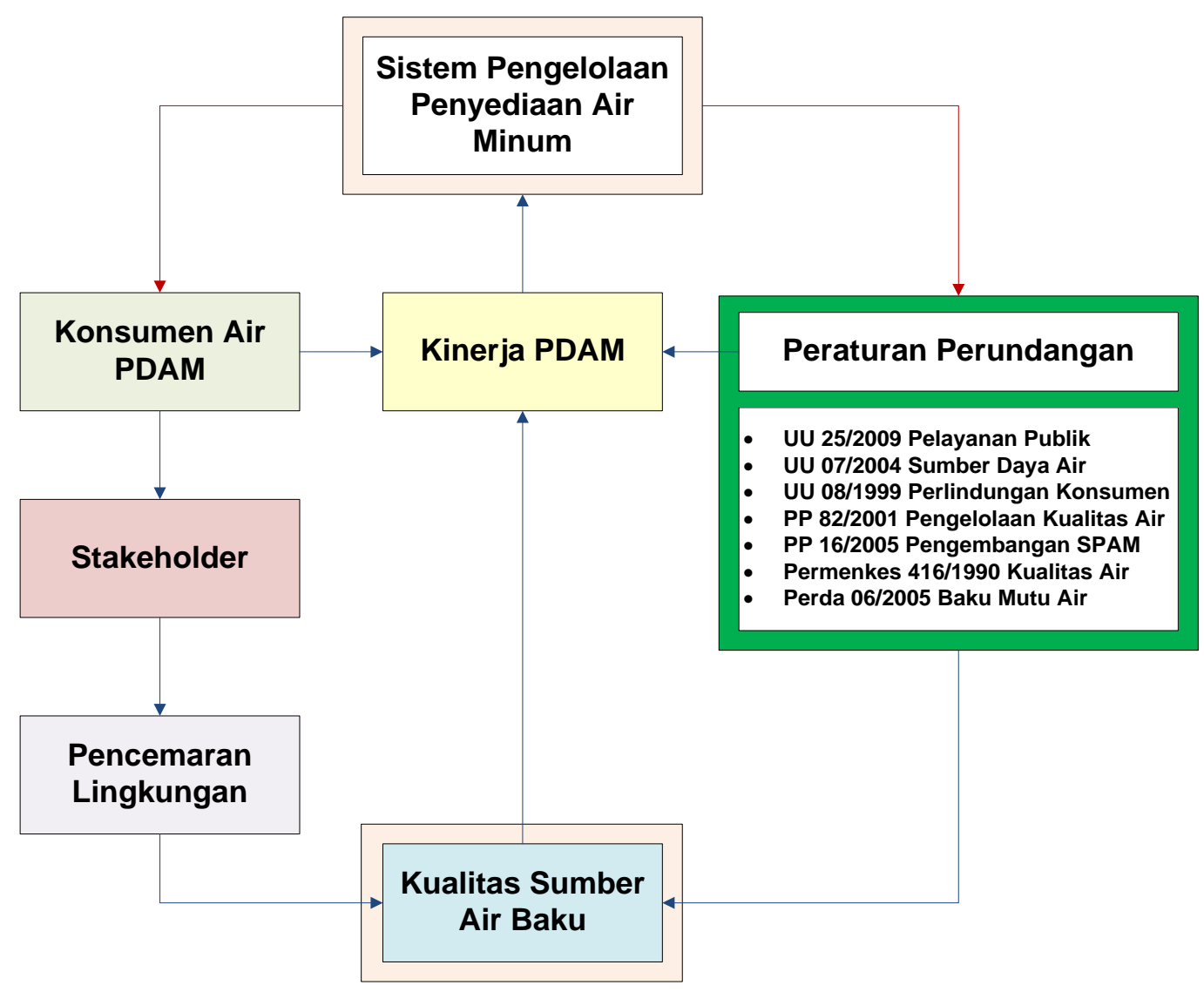

Gambar 1. Kerangka Pemikiran Penelitian

\section{HASIL DAN PEMBAHASAN}

\section{Persepsi Konsumen Terhadap Kualitas} Air

Dilihat dari persepsi masyarakat sebagai konsumen terhadap kualitas air PDAM diketahui bahwa, nilai rerata responden tertinggi berada pada pernyataan "Kelancaran air PDAM Tirta Dharma (selalu mengalir setiap diperlukan/mengalir lebih dari 12 jam per hari)" dengan nilai rerata sebesar 2,73 (cukup baik). Sedangkan rata-rata skor dari jawaban responden terendah terdapat pernyataan "Setiap keluhan terhadap air PDAM ditanggapi dengan cepat oleh petugas PDAM" sebesar 1,73 (sangat tidak baik). Rata-rata skor dari jawaban responden secara keseluruhan mengenai kualitas air PDAM dilihat dari persepsi masyarakat memiliki skor sebesar 2,28 (kategori tidak baik).

\section{Persepsi Manajemen PDAM Terhadap Kualitas Air}

Rata-rata skor dari jawaban responden terhadap kualitas air PDAM dilihat berdasarkan persepsi manajemen PDAM yaitu sebesar 3,24 (kategori cukup baik), dimana rata-rata skor jawaban tertinggi responden terdapat pada pernyataan "Air PDAM Tirta Dharma tidak berbau" sebesar 4,07 (baik). Sedangkan skor rata-rata jawaban terendah responden sebesar 3,13 terdapat pada pernyataan "Air sungai Bengkulu dapat dipakai untuk kebutuhan sehari-hari”. 


\section{Hasil Uji Kualitas Air}

Sampel air yang diuji sebanyak 5 sampel yang didapatkan dari :

S1 : sampel air di rumah masyarakat dengan range jauh, kelurahan Malabero

S2 : sampel air di rumah masyarakat dengan range sedang yaitu di kelurahan Kandang Limun
S3 : sampel air di rumah masyarakat dengan range dekat yaitu di kelurahan Surabaya

S4 : sampel air PDAM di reservoir PDAM Instalasi Pengolahan Air Surabaya

S5 : sampel air baku Sungai Bengkulu

Berdasarkan hasil pemeriksaan laboratorium terhadap kualitas air secara fisika dan kimia dapat dilihat pada tabel 1 sebagai berikut :

Tabel 1 Hasil Uji Kualitas Air Secara Fisika, Kimia, Bakteriologi

\begin{tabular}{|c|c|c|c|c|c|c|c|c|c|}
\hline \multirow[b]{2}{*}{ No } & \multirow[b]{2}{*}{ Parameter } & \multirow[b]{2}{*}{ Satuan } & \multirow{2}{*}{$\begin{array}{c}\text { Kadar Maks } \\
\text { yang } \\
\text { diperbolehkan }\end{array}$} & \multicolumn{5}{|c|}{ Hasil } & \multirow[b]{2}{*}{ Metode Uji } \\
\hline & & & & S1 & $\mathrm{S} 2$ & S3 & S4 & S5 & \\
\hline \multicolumn{10}{|c|}{ Fisik } \\
\hline 1 & $\mathrm{Bau}$ & - & Tidak berbau & $\begin{array}{l}\text { Tidak } \\
\text { berbau }\end{array}$ & $\begin{array}{l}\text { Tidak } \\
\text { berbau }\end{array}$ & $\begin{array}{l}\text { Tidak } \\
\text { berbau }\end{array}$ & $\begin{array}{l}\text { Tidak } \\
\text { berbau }\end{array}$ & $\begin{array}{l}\text { Tidak } \\
\text { berbau }\end{array}$ & Organoleptik \\
\hline 2 & Rasa & - & Tidak berasa & $\begin{array}{l}\text { Tidak } \\
\text { berasa }\end{array}$ & $\begin{array}{l}\text { Tidak } \\
\text { berasa }\end{array}$ & $\begin{array}{l}\text { Tidak } \\
\text { berasa }\end{array}$ & $\begin{array}{l}\text { Tidak } \\
\text { berasa }\end{array}$ & $\begin{array}{l}\text { Tidak } \\
\text { berasa }\end{array}$ & Organoleptik \\
\hline 3 & Suhu & ${ }^{\circ} \mathrm{C}$ & $\begin{array}{c}\text { Suhu udara } \\
\pm 3{ }^{\circ} \mathrm{C}\end{array}$ & $28^{\circ} \mathrm{C}$ & $28,5^{\circ} \mathrm{C}$ & $28,5^{\circ} \mathrm{C}$ & $28^{\circ} \mathrm{C}$ & $2,8 \circ \mathrm{C}$ & Conductivity \\
\hline 4 & Warna & $\mathrm{TCU}$ & 50 & 51 & 25 & 32 & 45 & - & Spektrofotometer \\
\hline 5 & Kekeruhan & NTU & 25 & 28 & 25 & 42 & 24 & - & Spektrofotometer \\
\hline 6 & $\begin{array}{l}\text { Zat padat } \\
\text { terlarut } \\
\text { (TDS) }\end{array}$ & $\mathrm{mg} / \mathrm{L}$ & 1.500 & 1250 & 1300 & 1600 & 1600 & 1795 & Conductivity \\
\hline \multicolumn{10}{|c|}{ Kimia } \\
\hline 1 & Kadmium & $\mathrm{mg} / \mathrm{L}$ & 0,005 & 0,042 & 0,039 & 0,016 & 0,014 & 0,201 & Spektrofotometer \\
\hline 2 & $\mathrm{Ph}$ & - & $6,5-9,0$ & 6,5 & 7,9 & 7,0 & 6,3 & 7,3 & Potensiometri \\
\hline 3 & Timbal & $\mathrm{mg} / \mathrm{l}$ & 0,03 & - & - & - & - & 0,33 & AAS \\
\hline \multicolumn{10}{|c|}{ Total Coliform } \\
\hline 1 & Coliform & & $\begin{array}{c}10 / 100 \mathrm{ml} \\
1000 / 100 \mathrm{ml}\end{array}$ & $>1898$ & 233 & $\begin{array}{c}>189 \\
8\end{array}$ & 233 & $\begin{array}{c}>189 \\
8\end{array}$ & \\
\hline
\end{tabular}

Sumber : Hasil Penelitian, 2014

Rujukan Baku Mutu :

PerMenKes No. 416/MENKES/Per/IX/1990 tentang Persyaratan Kualitas Air Bersih.

Peraturan Daerah Propinsi Bengkulu No. 6 tahun 2005 tentang Penetapan baku mutu air dan kelas air sungai lintas kabupaten/kota dalam Propinsi Bengkulu.

Hasil pemeriksaan kualitas air dilihat dari pemeriksaan secara fisika, kimia dan golongan coliform, diketahui bahwa pada sampel S1, S3 memiliki kekeruhan melebihi batas maksimal yang diperbolehkan, dimana hasil pada S1 dan S3 yaitu 28 dan 42 NTU (kadar maksimal $=25 \mathrm{NTU})$. Pada parameter zat padat terlarut, memiliki kadar maksimal yang diperbolehkan sebanyak $1.500 \mathrm{ml} / \mathrm{L}$, hasil pengujian laboratorium menunjukkan adanya kadar yang melebihi batas diperbolehkan pada sampel air S3, S4, dan $\mathrm{S} 5$ (1.600 mg/L, $1.600 \mathrm{mg} / \mathrm{L}, 1.795 \mathrm{mg} / \mathrm{L})$. Kadar kadmium pada 5 sampel air, memiliki kadar yang melebihi batas diperbolehkan, dimana batas maksimal yang diperbolehkan sebesar $0,005 \mathrm{mg} / \mathrm{L}$ untuk air bersih dan $0,01 \mathrm{mg} / \mathrm{l}$ untuk air kelas I. pada sampel didapatkan hasil $\mathrm{S} 1=$ $0,042 \mathrm{mg} / \mathrm{L} ; \mathrm{S} 2=0,039 \mathrm{mg} / \mathrm{L} ; \mathrm{S} 3=0,016$ $\mathrm{mg} / \mathrm{L} ; \mathrm{S} 4=0,014 \mathrm{mg} / \mathrm{L}$ dan $\mathrm{S} 5=0,201$ 
mg/L. Sedangkan kadar Timbal hanya ditemukan pada sampel S5 yaitu pada sampel air baku Sungai Kota Bengkulu sebesar 0,3 ppm.

\section{Hasil Analisis Importance-Performance Analysis}

Metode Importance Performance Analysis untuk mengetahui tingkat kesesuaian dan faktor-faktor yang menjadi prioritas utama dalam peningkatan kualitas pelayanan air PDAM Tirta Dharma. Ke-13 variabel yang telah valid tersebut yaitu sebagai berikut:

a. Faktor Tangibles (berwujud)

1. Air PDAM memiliki air yang jernih.

2. Air PDAM Tirta Dharma tidak berasa.

3. Air PDAM Tirta Dharma tidak berbau.

4. Volume air PDAM Tirta Dharma yang keluar besar.

b. Faktor Reliability (kehandalan)

1. Kelancaran air PDAM Tirta Dharma (selalu mengalir setiap diperlukan/mengalir lebih dari 12 jam per hari).

c. Faktor Responsiveness (keresponsifan)
1. Setiap keluhan terhadap air PDAM ditanggapi dengan cepat oleh petugas PDAM.

d. Faktor Competence (kompetensi)

1. Terdapat jadwal pemeriksaan pipa PDAM yang dilakukan secara rutin.

e. Faktor Courtesy (Perilaku)

1. Petugas rutin melakukan pemeliharan meteran air PDAM Tirta Dharma ditempat konsumen.

f. Faktor Security (keamanan)

1. Air PDAM tidak mengandung zat kimia beracun.

2. Air PDAM tidak mengandung bakteri patogen.

3. Air Sungai Bengkulu bebas dari pencemaran zat-zat kimia beracun.

4. Air Sungai Bengkulu dapat terus dipakai untuk air baku PDAM.

5. Air Sungai Bengkulu dapat dipakai untuk kebutuhan sehari-hari.

Dari 13 variabel kuesioner didapatkan hasil perhitungan rata-rata dari faktor Tangibles, Reliability, Responsiveness, Competence, Courtesy dan Securtiy sebagai berikut :

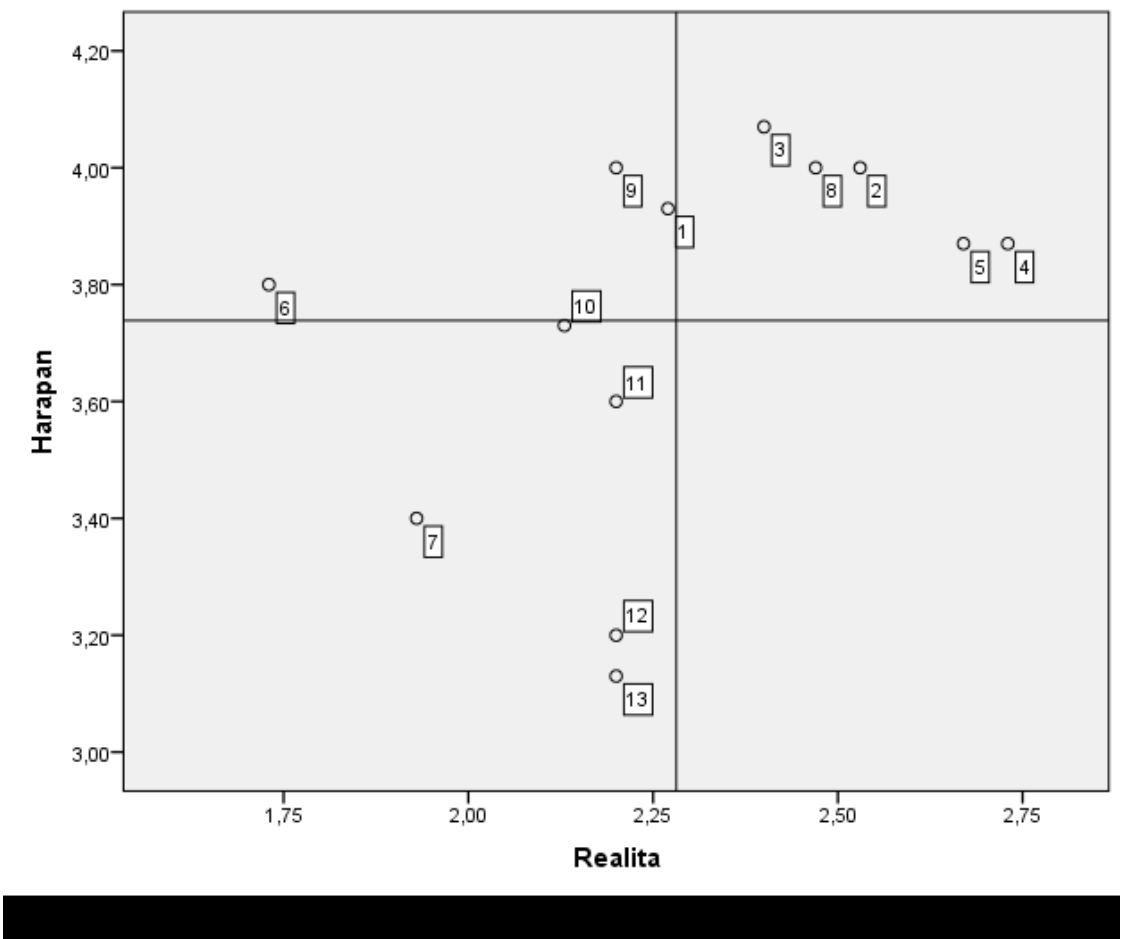

Gambar 2. Diagram Hasil Importance Performance Analysis 
Dari Gambar 2 ini terlihat bahwa letak dari unsur-unsur pelaksanaan faktorfaktor yang mempengaruhi persepsi konsumen dan manajemen terhadap kualitas air PDAM Tirta Dharma terbagi menjadi 4 bagian. Adapun interpretasi dari diagram kartesius tersebut dapat dijelaskan sebagai berikut :

\section{Kuadran A}

Menunjukkan faktor-faktor yang mempengaruhi persepsi konsumen dan manajemen terhadap kualitas air PDAM Tirta Dharma, karena keberadaan faktor-faktor inilah yang dinilai sangat penting oleh konsumen. Faktor-faktor yang termasuk dalam kuadran ini yaitu :

a. Air PDAM memiliki air yang jernih.

b. Air PDAM tidak mengandung zat kimia beracun.

c. Setiap keluhan terhadap air PDAM ditanggapi dengan cepat oleh petugas PDAM.

\section{Kuadran B}

Menunjukkan faktor-faktor yang mempengaruhi persepsi konsumen dan manajemen terhadap kualitas air PDAM Tirta Dharma berada dalam kuadran ini perlu dipertahankan, karena pada umumnya tingkat pelaksanaan telah sesuai dengan kepentingan dan harapan konsumen, sehingga dapat memuaskan konsumen terhadap kualitas air PDAM Tirta Dharma yang ada.

Faktor-faktor yang termasuk dalam kuadran ini adalah :

a. Air PDAM Tirta Dharma tidak berbau.

b. Petugas rutin melakukan pemeliharaan meteran air PDAM Tirta Dharma di rumah anda.

c. Air PDAM Tirta Dharma tidak berasa.

d. Volume air PDAM Tirta Dharma yang keluar besar.

e. Kelancaran air PDAM Tirta Dharma (selalu mengalir setiap diperlukan/mengalir lebih dari 12 jam per hari).

\section{Kuadran C}

Menunjukkan faktor-faktor yang mempengaruhi persepsi konsumen dan manajemen terhadap kualitas air PDAM Tirta Dharma berada dalam kuadran ini masih dianggap kurang penting oleh konsumen, sedangkan kualitas pelayanannya biasa saja atau cukup saja.

Faktor-faktor yang termasuk dalam kuadran ini adalah :

a. Pemeriksaan pipa PDAM dilakukan secara rutin.

b. Air Sungai Bengkulu bebas dari pencemaran zat-zat kimia beracun.

c. Air Sungai Bengkulu dapat terus dipakai untuk air baku PDAM.

d. Air Sungai Bengkulu dapat dipakai untuk kebutuhan sehari-hari.

\section{Kuadran D}

Menunjukkan faktor-faktor yang mempengaruhi persepsi konsumen dan manajemen terhadap kualitas air PDAM Tirta Dharma berada dalam kuadran ini dinilai berlebihan dalam pelaksanaannya, hal ini terutama disebabkan karena konsumen air PDAM Tirta Dharma menganggap tidak terlalu penting terhadap adanya faktor tersebut, akan tetapi pelaksanaannya dilakukan dengan baik sekali oleh pihak manajemen PDAM sehingga sangat memuaskan konsumen. Di dalam faktor courtesy ini tidak terdapat faktor-faktor yang masuk ke dalam kuadran D sehingga semua faktor-faktor reliability dianggap telah sesuai dengan harapan dan keinginan konsumen.

\section{PEMBAHASAN}

Berdasarkan data yang diperoleh dari penyebaran kuesioner, maka dapat diketahui karakteristik demografi responden konsumen pada penelitian ini berdasarkan rentang usia, responden berada pada rentang usia 41-50 tahun (60\%). Dengan demikian sebagian besar responden yang diteliti adalah responden dengan usia dewasa, dan memiliki tingkat 
pendidikan terakhir SMA sebanyak 60\%, dengan lama pemakaian air PDAM lebih dari 10 tahun $(60 \%)$.

Pengetahuan mengenai kondisi kualitas air sungai Kota Bengkulu yang dicerminkan oleh nilai konsentrasi beberapa parameter kualitas air baik secara fisika, kimia maupun secara biologi.

Suhu merupakan salah satu faktor yang sangat penting dalam proses metabolisme organisme diperairan. Hasil pengukuran suhu sampel air tidak memperlihatkan variasi yang besar, bahkan relatif stabil yaitu berkisar antara 28$28,5{ }^{\circ}$ C. Suhu air mempunyai peranan dalam mengatur kehidupan biota perairan terutama dalam proses metabolisme, kenaikan suhu menyebabkan terjadinya peningkatan konsumsi oksigen.

Kualitas air PDAM dilihat dari hasil pemeriksaan laboratorium menandakan, masih terdapatnya parameter fisika, kimia dan bakteriologi (golongan coliform) yang melebihi kadar maksimal diperbolehkan. Hal ini terlihatnya, masih tingginya angka kekeruhan, zat padat terlarut, adanya kadmium dan timbal serta masih tingginya angka coliform.

Kekeruhan merupakan parameter parameter yang digunakan untuk menyatakan derajat kegelapan di dalam air yang disebabkan oleh bahan-bahan yang melayang. Dari hasil analisis kualitas air menunjukkan bahwa nilai kekeruhan air PDAM berkisar antara 24-42 NTU. Permenkes No. 416 Tahun 1990 mensyaratkan nilai kekeruhan air bersih maksimal 25 NTU. Kekeruhan biasanya terdiri dari partikel anorganik yang berasal dari erosi DAS. Kekeruhan memiliki korelasi positif dengan padatan tersuspensi, yaitu semakin tinggi nilai kekeruhan maka semakin tinggi pula nilai padatan tersuspensi., dengan demikian air PDAM tidak memenuhi syarat sebagai sumber air bersih.

Hasil pengukuran total padatan terlarut (TDS) air PDAM berkisar antara 1.250-1.600 mg/l, dimana kadar maksimal yang diizinkan $1.500 \mathrm{mg} / \mathrm{l}$, sedangkan hasil pengukuran total padatan terlarut (TDS) air Sungai Bengkulu 1795 mg/l melebihi kadar maksimum yang diperbolehkan $1000 \mathrm{mg} / \mathrm{l}, \quad$ (adanya perbedaan baku mutu berdasarkan PP no. 82 tahun 2001 pasal 12 yang menyebutkan bahwa pemerintah propinsi dapat menetapkan baku mutu air lebih ketat dari $\mathrm{k}$ riteria mutu air yang ditetapkan). Tingginya nilai total padatan terlarut menggambarkan bahwa padatan yang masuk ke air sungai Bengkulu lebih banyak yang berbentuk padatan yang ukurannya kecil (padatan terlarut), atau padatan yang terdapat diperairan air Sungai Bengkulu lebih didominasi oleh padatan yang berasal dari limbah-limbah organik.

Derajat keasaman atau $\mathrm{pH}$ merupakan nilai yang menunjukkan aktivitas ion hidrogen dalam air. Pengukuran $\mathrm{pH}$ pada saat pengambilan sampel terlihat bahwa pada 5 sampel air cenderung bersifat basa dengan kisaran 6,5-7,9. Hal ini masih masuk dalam batas $\mathrm{pH}$ yang diperbolehkan yaitu 6,5-9,0. Nilai $\mathrm{pH}$ suatu perairan dapat mencerminkan keseimbangan antar asam dan basa dalam perairan tersebut. Semakin tinggi $\mathrm{pH}$ suatu perairan maka makin besar sifat basanya, demikian juga sebaliknya, semakin rendah nilai $\mathrm{pH}$ maka semakin asam suatu perairan. Nilai $\mathrm{pH}$ dipengaruhi oleh beberapa parameter, antara lain aktivitas biologi, suhu, kandungan oksigen dan ionion. Dari aktivitas biologi dihasilkan gas $\mathrm{CO}_{2}$ yang merupakan hasil respirasi. Gas ini akan membentuk ion buffer atau penyangga untuk menjaga kisaran $\mathrm{pH}$ di perairan agar tetap stabil (Pescod, 1978). Dalam mdia dengan $\mathrm{pH}$ rendah, ion hidrogrn dalam air mengurangi alkalinitas (Saeni, 2009).

Kadar kadmium pada 5 sampel air, memiliki kadar yang melebihi batas diperbolehkan, dimana batas maksimal yang diperbolehkan sebesar 0,005 mg/L. pada sampel didapatkan hasil $\mathrm{S} 1=0,042$ $\mathrm{mg} / \mathrm{L} ; \mathrm{S} 2=0,039 \mathrm{mg} / \mathrm{L} ; \mathrm{S} 3=0,016 \mathrm{mg} / \mathrm{L}$; $\mathrm{S} 4=0,014 \mathrm{mg} / \mathrm{L}$ dan $\mathrm{S} 5=0,201 \mathrm{mg} / \mathrm{L}$. 
nilai rata-rata konsentrasi cadmium dari air PDAM adalah 0,0624 mg/L. Tingginya konsentrasi tersebut disebabkan oleh aktivitas manusia melalui limbah kota dan docking kapal yang berasa di sungai. Masih ditemukannya kadar kadmium pada air PDAM dikarenakan proses pengolahan air PDAM Tirta Dharma, dimana air baku yang masuk ke dalam bak pengumpul air baku di instalasi pengolahan, hanya diberikan penambahan bahan kimia/koagulan pengikat kotoran yaitu Poly Aluminium Choride (PAC), dan dilakukan proses filter/penyaringan flok yang ada, akan tetapi proses ini belum begitu efektif untuk mengurangi kadar kadmium.

Adanya peningkatan kadar kadmium dari reservoir ke tempat penyaluran ke range jauh, dimana terlihat kadar kadmium pada reservoir sebesar $0,014 \mathrm{mg} / \mathrm{L}$, range dekat $0,016 \mathrm{mg} / \mathrm{L}$, range sedang $0,039 \mathrm{mg} / \mathrm{L}$ dan range jauh $0,042 \mathrm{mg} / \mathrm{L}$, hal ini kemungkinan disebabkan karena terjadinya korosi pada pipa penyaluran, sehingga semakin jauh semakin banyak pipa korosi yang dilewati dan semakin tinggi kadar kadmiumnya. Pengaruh kadmium pada manusia sangat serius, diantaranya menyebabkan tekanan darah tinggi, kerusakan ginjal, kerusakan jaringan testikuler dan kerusakan sel-sel darah merah (Effendi, 2003). Hal ini harus segera ditindaklanjuti oleh PDAM karena sesuai dengan amanant Undang-Undang No. 8 tahun 1999, Pasal 8 Ayat 2 tentang Pelayanan Publik ; Pelaku usaha dilarang memperdagangkan barang yang rusak, cacat atau bekas, dan tercemar tanpa memberikan informasi secara lengkap dan benar atas barang dimaksud.

Ditemukannya kadar Timbal pada sampel air baku Sungai Bengkulu sebesar 0,33 ppm, hal ini dikarenakan terjadinya pengendapan akibat besarnya adsorpsi oleh padatan tersuspensi.. Adanya kadar Timbal di sungai Bengkulu dapat disebabkan oleh tingginya aktivitas dari kapal-kapal nelayan yang keluar masuk di daerah tersebut, dan adanya area industri. Kondisi ini dapat mengakibatkan adanya ceceran atau tumpahan bahan bakar yang masuk ke perairan sehingga konstentrasi logam $\mathrm{Pb}$ terlarut meningkat. Selain itu, terjadi peningkatan konsentrasi di daerah Sungai Bengkulu disebabkan oleh adanya masukan bahan pencemar yang berasal dari penduduk disekitar Sungai Bengkulu.

Daya racun timbal yang akut pada perairan alami menyebabkan kerusakan hebat pada ginjal, system reproduksi, hati dan otak serta system syaraf sentral dan bisa menyebabkan kematian (Rukaesih, 2004).

Timbal ditemukan dengan kadar 0,33 ppm pada air baku Sungai Bengkulu, akan tetapi di reservoir PDAM dan pada air PDAM di masyarakat tidak ditemukan kadar timbal, hal ini dikarenakan adanya proses pengolahan fisik di PDAM yaitu dimana air baku dari Sungai Bengkulu ditambahkan zat klorin dimana terjadi pengendapan ion $\mathrm{Pb}^{2+}$ oleh $\mathrm{Cl}^{-}$berupa padatan putih yang sukar larut dalam air, selain itu adanya beberapa kali proses perlakuan pada air di reservoir dapat juga mengakibatkan pengendapan dari Timbal.

Pengujian konsentrasi bakteri coliform merupakan indikator keberadaan bakteri dan virus pathogen (Wiryono,2012). Tingginya nilai kandungan bakteri coliform yang didapatkan pada penelitian ini, secara umum menggambarkan bahwa kandungan bakteri coliform di atas batas yang diizinkan. Kondisi ini dapat membahayakan kesehatan penduduk yang menggunakan air PDAM. Penyakit yang disebabkan oleh pathogen di air antara lain kolera, tifus, disentri, polio dan hepatitis. Masing-masing penyakit disebabkan oleh bakteri dan organism lain yang spesifik (Chiras and Reganold, 2005 dalam Wiryono 2012).

Dilihat dari persepsi masyarakat diperoleh rata-rata skor jawaban sebesar 2,28 (tidak baik) yang menandakan bahwa kualitas air belum baik, hal ini selaras dengan banyaknya keluhan masyarakat Kota Bengkulu yang melihat secara visual 
telah terjadi pencemaran sungai air Bengkulu terutama peningkatan kekeruhan akibat penambangan batubara, karena maraknya penambangan batubara di sungai air Bengkulu, juga terlihat dari pernyataan masyarakat bahwa manajemen belum baik dalam menangani keluhan yang disampaikan masyarakat mengenai air PDAMBerdasarkan persepsi manajemen, diperoleh skor rata-rata sebesar 3,24 (cukup baik), hal ini menandakan bahwa pihak manajemen berpendapat bahwa kualitas air PDAM telah cukup baik, hal ini didukung dengan pernyataan dari manajemen bahwa air PDAM tidak berbau. Berdasarkan importance performance analysis maka hendaknya dilihat pengukuran faktor tingkat kinerja dan tingkat kepentingan, dengan dibagi menjadi 4 kuadran. Dimana pada kuadran kedua merupakan faktor penunjang bagi kepuasan konsumen sehingga pihak manajemen berkewajiban memastikan bahwa kinerja institusi yang dikelolanya dapat terus mempertahankan prestasi yang telah dicapai, antara lain dengan berkoordinasi dengan Pemda dan dinas terkait untuk konservasi kawasan hulu Sungai Bengkulu, penambahan reservoir serta peningkatan SDM PDAM Tirta Dharma guna peningkatan kualitas

\section{KESIMPULAN}

Berdasarkan hasil penelitian yang dilakukan di PDAM Kota Bengkulu, pada dasarnya harus mencari alternatif sumber baru air baku PDAM dikarenakan kualitas air PDAM tidak memenuhi standar yang dipersyaratkan sesuai dengan Per MenKes Nomor: 416/Men.Kes/PER /IX/1990 Tentang Syarat-syarat dan Pengawasan Kualitas Air dan kualitas air baku Sungai Bengkulu tidak memenuhi standar yang dipersyaratkan dalam Peraturan Daerah Propinsi Bengkulu No. 6 Tahun 2005 tentang Penetapan Baku Mutu Air dan Kelas Air Sungai Lintas Kabupaten/Kota dalam Propinsi Bengkulu selain itu pihak manajemen perlu terus melakukan tindakan perbaikan dalam menangani keluhan pelanggan/masyarakat terhadap kualitas air yang ada, kemudian dilakukan kontrol berkala terhadap kualitas air PDAM yang ada serta tetap memperhatikan pipa penyaluran air, sehingga tidak menyebabkan adanya cemaran kimia tambahan yang disebabkan oleh korosi pipa, karena sebagai penyelenggara jasa publik, PDAM wajib menjamin mutu barang dan/atau jasa yang di produksi berdasarkan ketentuan standar mutu/jasa yang berlaku ( Undang-Undang No. 8 Tahun 1999 tentang perlindungan konsumen).

Dari hasil analisis IPA, ada 3 faktor yang harus menjadi prioritas utama pihak manajemen yaitu :

a. Air PDAM memiliki air yang jernih.

b. Air PDAM tidak mengandung zat kimia beracun.

c. Setiap keluhan terhadap air PDAM ditanggapi dengan cepat oleh petugas PDAM.

Berdasarkan hasil penelitian yang telah dilakukan perlu dicarikan alternatif sumber bahan baku yang baru untuk PDAM Kota Bengkulu dikarenakan kualitas air baku Sungai Bengkulu tidak memenuhi standar yang dipersyaratkan sesuai dengan PerMenKes Nomor: 416/Men.Kes/ PER/IX/1990 Tentang Syarat-syarat dan Pengawasan Kualitas Air dan Peraturan daerah Propinsi Bengkulu No. 6 Tahun 2005 tentang Penetapan Baku Mutu Air dan Kelas Air Sungai Lintas Kabupaten/Kota dalam Propinsi Bengkulu. Berdasarkan PP Nomor 16 Tahun 2005 tentang Pengembangan Sistem Penyediaan Air Minum (SPAM) disebutkan pada ayat (1) "Air baku wajib memenuhi baku mutu yang ditetapkan untuk penyediaan air minum sesuai dengan Peraturan perundang-undangan”. Manajemen PDAM wajib meningkatkan kualitas pelayanan terkait penanganan keluhan pelanggan, guna meningkatkan pelayanan publik yang ada di PDAM Tirta Dharma Kota Bengkulu, dimana berdasarkan Undang- 
Undang No. 25 Tahun 2009 Tentang Pelayanan Publik pada pasal 18 poin c, masyarakat sebagai konsumen mempunyai

\section{DAFTAR PUSTAKA}

Aini. 2012. Importance Performance Analysis. Digital Library ITB. Bandung

Balai Lingkungan Hidup (BLH) Propinsi Bengkulu, Analisis Kualitas Air dari pertambangan batubara, 2012.

Effendi,Effni. 2003. Telaah Kualitas Air Bagi Pengelolaan Sumber Daya Alam dan lingkungan Perairan. Kanisius. Yokyakarta

Herman, Danny. 2006. Tinjauan Terhadap Tailing Mengandung Unsur Pencemar Arsen (As), Merkuri $(\mathrm{Hg})$, Timbal $(\mathrm{Pb})$ dan Kadmium $(\mathrm{Cd})$ dari Sisa Pengolahan Biji Logam. Jurnal Geologi Indonesia, Vol 1 No. 1 Maret 2006. Bandung

Kepmenkes RI No. 416/MENKES /SK/IX/1990 Tentang Syarat-Syarat dan Pengawasan Kualitas Air.

Miranda, F.J., Antonio Chamorro, Luis R. Murillo, Juan Vega, 2010. An Importance-Performance Analysis of Primary Health Care Services: Managers vs. Patients Perceptions. J. Service Science \& Management 3:227-234.

PDAM. 2013. Buletin PDAM Tirta Dharma. Bengkulu

PDAM. 2013. Laporan Tahunan PDAM Tirta Dharma. Bengkulu

Peraturan Daerah Propinsi Bengkulu Nomor 6 Tahun 2005 Tentang Penetapan Baku Mutu Air dan Kelas Air Sungai Lintas Kabupaten/Kota Dalam Propinsi Bengkulu.

Peraturan Pemerintah No. 16 Tahun 2005 Tentang Pengembangan Sistem Penyediaan Air Minum. hak untuk mendapatkan tanggapan terhadap pengaduan yang diajukan.

Peraturan Pemerintah No. 82 Tahun 2001 Tentang Pengelolaan Kualitas Air.

Rukaesih, Achmad. 2004. Kimia Lingkungan. Penerbit Andi. Yokyakarta

Saeni,M.S. 2009. Kimia Lingkungan. IPB.Bogor

Sekaran. 2006. Metodologi Penelitian Untuk Bisnis. Salemba Empat. Jakarta

Subagyo, Joko. 2002. Hukum Lingkungan, Masalah dan Penanggulangannya. PT. Rineka Cipta. Jakarta.

SPT Gubernur Bengkulu No. 80/3340/KBPIM. Hasil Pemantauan Kualitas Air Sungai Bengkulu. Tanggal 24 Mei 2011.

Undang-Undang No. 8 Tahun 1999 Tentang Perlindungan konsumen.

Undang-Undang No. 25 Tahun 2009 Tentang Pelayanan Publik.

Undang-Undang No. 7 Tahun 2004 Tentang Sumber Daya Air.

Wade, D.J., Paul F.J. Eagles. 2003. The Use of Importance-Performance Analysis and Market Segmentation for Tourism Management in Parks and Protected Areas: An Application to Tanzania's National Parks. Journal of Ecotourism 2(3):196-212.

Wiryono. 2012. Pengantar Ilmu Lingkungan. Badan Penerbitan Fakultas Pertanian UNIB Bengkulu.

Wong, M.S., Nishimoto Hideki2 and Philip George. 2010, The Use of Importance-Performance Analysis (IPA) in Evaluating Japan's Egovernment Services. Journal of Theoritical and Applied Electronic Commerce Research 6(2):17-30. 